\title{
EFFECT OF IMPLANTATION AND ANNEALING REGIMES ON ION-BEAM SYNTHESIS OF InAs NANOCRYSTALS *
}

\author{
F. Komarov ${ }^{\text {a }}$, L. Vlasukova ${ }^{\text {a }}$, O. Milchanin ${ }^{\text {a }}$, A. Komarov ${ }^{\text {a }}$, W. Wesch ${ }^{\text {b }}$, and \\ A.K. Togambayeva ${ }^{\mathrm{c}}$ \\ a Belarusian State University, Nezavisimosti Ave. 4, 220030 Minsk, Belarus \\ E-mail: komarovf@bsu.by \\ ${ }^{\mathrm{b}}$ Institut für Festkörperphysik, Friedrich-Schiller-Universität Jena, Max-Wien-Platz 1, D-07743 Jena, Germany \\ ${ }^{c}$ Al-Farabi Kazakh National University, Almaty, Kazakhstan
}

Received 10 October 2008; revised 12 March 2009; accepted 19 March 2009

\begin{abstract}
We reported the formation of nanosized InAs crystallites in silicon wafers by means of As $\left(245 \mathrm{keV}, 4.1 \cdot 10^{16} \mathrm{~cm}^{-2}\right)$ and In $\left(350 \mathrm{keV}, 3.7 \cdot 10^{16} \mathrm{~cm}^{-2}\right)$ implantation. The implantation was carried out at 25 and $500^{\circ} \mathrm{C}$. In order to verify the effect of getter on precipitates growth an additional procedure was carried out for the samples implanted with As and In species at the room temperature. This procedure included the implantation of $\mathrm{H}_{2}^{+}$ions with the energy of $100 \mathrm{keV}$ at $1.2 \cdot 10^{16} \mathrm{~cm}^{-2}$. Afterwards, the samples were annealed at $900{ }^{\circ} \mathrm{C}$ for $60 \mathrm{~min}$ in inert ambient. In order to characterize the implanted layers, Rutherford backscattering spectrometry in combination with the channelling (RBS / C) and transmission electron microscopy (TEM) techniques were used. TEM has revealed InAs nanocrystals in implanted samples after the annealing. It has been shown that average size and size distribution of InAs clusters depend on implantation temperature and annealing duration. Significant diffusional redistribution of implanted species has been revealed after "hot" implantation and post-implantation annealing. We have suggested that it is caused by non-equilibrium diffusion. The radiation-enhanced diffusivities at "hot" implantation have been determined for the abovementioned experimental conditions.
\end{abstract}

Keywords: crystalline silicon, high-fluence implantation of As and In ions, InAs nanocrystals

PACS: 61.46.-w, 61.72.Tt, 68.37.Lp, 78.67.Bf

\section{Introduction}

InAs is a narrow-gap $\mathrm{A}^{3} \mathrm{~B}^{5}$ semiconductor with direct gap. Synthesis of InAs quantum dots inside the crystalline $\mathrm{Si}$ is of interest for applications in optoelectronic devices operating in IR range. MBE-technique has been used for the formation of an ensemble of InAs clusters on the $\mathrm{Si}(001)$ [1]. Such clusters covered with a Si cap layer show intense luminescence at $1.3 \mu \mathrm{m}$ at $7 \mathrm{~K}$. The other technique for fabricating of III-V quantum dots is high-fluence ion implantation followed by thermal treatment. InAs nanoclusters have been formed using this method in $\mathrm{Si}$ and $\mathrm{SiO}_{2}$ [2,3]. The advantage of ion implantation is its compatibility with industrial device production lines. In our previous paper [4] we have reported the formation of InAs nanoclusters in Si matrix by high-fluence ion implantation at the elevated tem-

\footnotetext{
* Results presented at the international conference Radiation Interaction with Material and Its Use in Technologies 2008, 24-27 September 2008, Kaunas, Lithuania
}

perature followed with the annealing. Modifying the regimes of implantation and post-implantation annealing may provide a way to control the size and crystalline quality of the compound precipitates thus formed.

The aim of this work is to study the effects of the implantation and annealing regimes on ion-beam synthesis of InAs nanocrystals. We also present the depth concentration profiles of In and As atoms implanted in silicon at room and elevated temperature and analyse a diffusional redistribution of embedded impurity due to the post-implantation annealing.

\section{Experiment}

Single-crystalline $n$-doped (100) Si wafers were implanted subsequently with As and In ions. In accordance with [3] such a sequence of implantation results in the formation of smaller InAs crystals with a more 


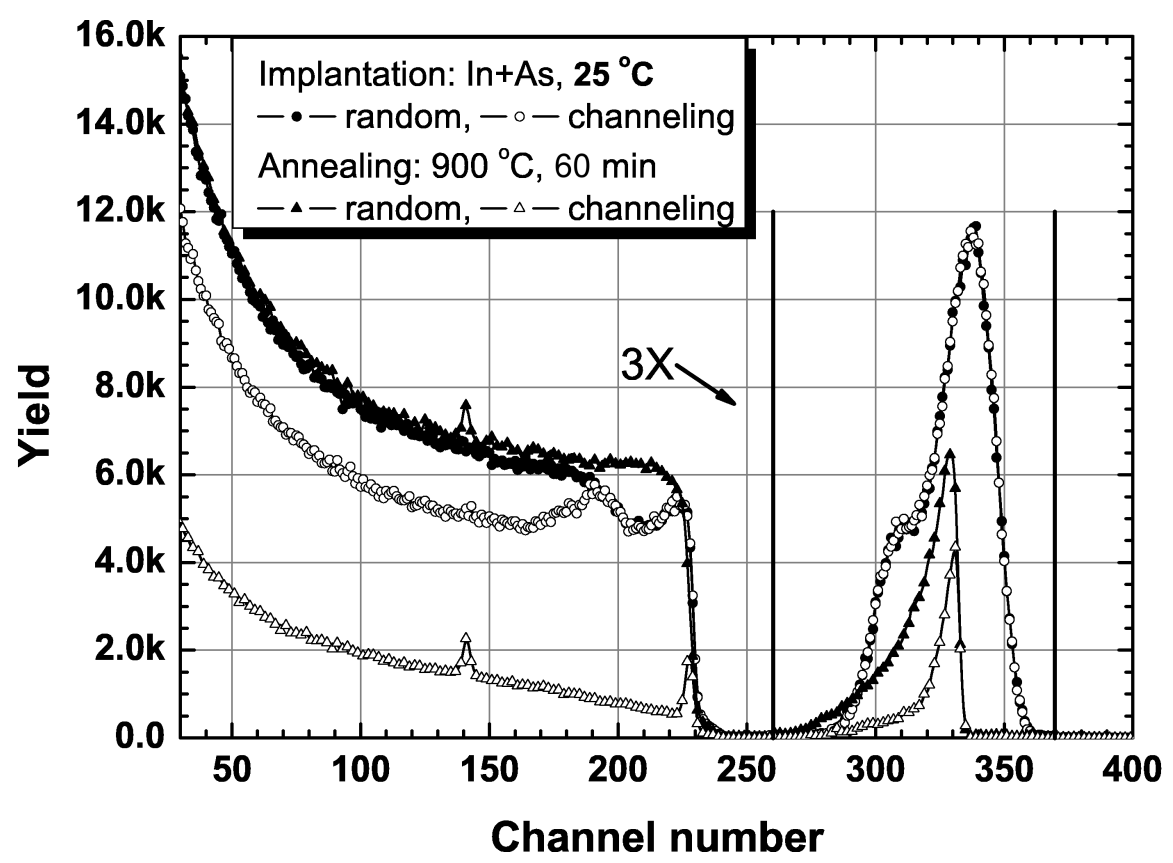

Fig. 1. RBS spectra of the Si sample implanted at the room temperature with As $\left(245 \mathrm{keV}, 4.1 \cdot 10^{16} \mathrm{~cm}^{-2}\right)$ and $\operatorname{In}\left(350 \mathrm{keV}, 3.7 \cdot 10^{16} \mathrm{~cm}^{-2}\right)$.

uniform size distribution in comparison with the case of In ions implanting first. In order to evaluate the effect of the implantation temperature a part of samples was implanted at the room temperature and another one at $500{ }^{\circ} \mathrm{C}$. The ion energies and fluencies for arsenic were $245 \mathrm{keV}$ and $4.1 \cdot 10^{16} \mu \mathrm{m}^{-2}$ and for indium $350 \mathrm{keV}$ and $3.7 \cdot 10^{16} \mu \mathrm{m}^{-2}$. In order to obtain maximum impurity concentrations of $\approx 4.5 \cdot 10^{21} \mathrm{~cm}^{-3}$ at a depth of approximately $150-180 \mathrm{~nm}$ for both ion species, the distributions of species to be implanted were calculated by the SRIM'2003 code. In order to verify the effect of getter on precipitates growth an additional procedure was carried out for the samples implanted with As and In ions at the room temperature. This procedure included the implantation of $\mathrm{H}_{2}^{+}$ions with the energy of $100 \mathrm{keV}$ at a fluence of $1.2 \cdot 10^{16} \mathrm{~cm}^{-2}$. It was performed to create a deep damaged layer acting as an inner getter during the post-implantation annealing. Afterwards, the part of samples were annealed in an inert ambient at $900{ }^{\circ} \mathrm{C}$ for $60 \mathrm{~min}$. The depth distributions of As and In into the silicon matrix were analysed using RBS. In all cases the RBS measurements were performed with $1.4 \mathrm{MeV}$ $\mathrm{He}^{+}$. The structural-phase modifications after annealing have been studied by means of transmission electron microscopy in cross-section $(\mathrm{X})$ geometry using a Hitachi H-800 instrument operating at $200 \mathrm{keV}$.

\section{Results and discussion}

\subsection{RBS data}

Figure 1 represents RBS spectra of as-implanted at room temperature and annealed samples. At the random spectra one can see the implantation at the room temperature results in an amorphous layer formation in subsurface region. In the region of $\mathrm{He}^{+}$ions backscattering at impurities (channel numbers from 340 to 460) a superimposing of peaks from As and In is observed. The RBS spectra of room temperature implanted samples with getter and without it are entirely coincided. Due to this reason the RBS spectra of the samples with the getter are not shown. A comparison of random spectra of as-implanted and annealed samples reveals the impurity redistribution owing to intensive diffusion towards the surface and into the bulk during the annealing. Analysis of random and aligned spectra indicates the incorporation of more than a half of impurity atoms into the regular lattice sites for the room temperature implanted samples after the annealing.

Figure 2 shows RBS spectra of as-implanted at elevated temperature and annealed samples. At the random spectrum a "downfall" in the region of channel numbers from 180 to 200 is less expressed in comparison with a case of the room temperature implanted samples. The intensities of embedded impurities peaks are smaller, too. An increasing of the yield of backscattered $\mathrm{He}^{+}$ions in the region of channel numbers from 170 to 


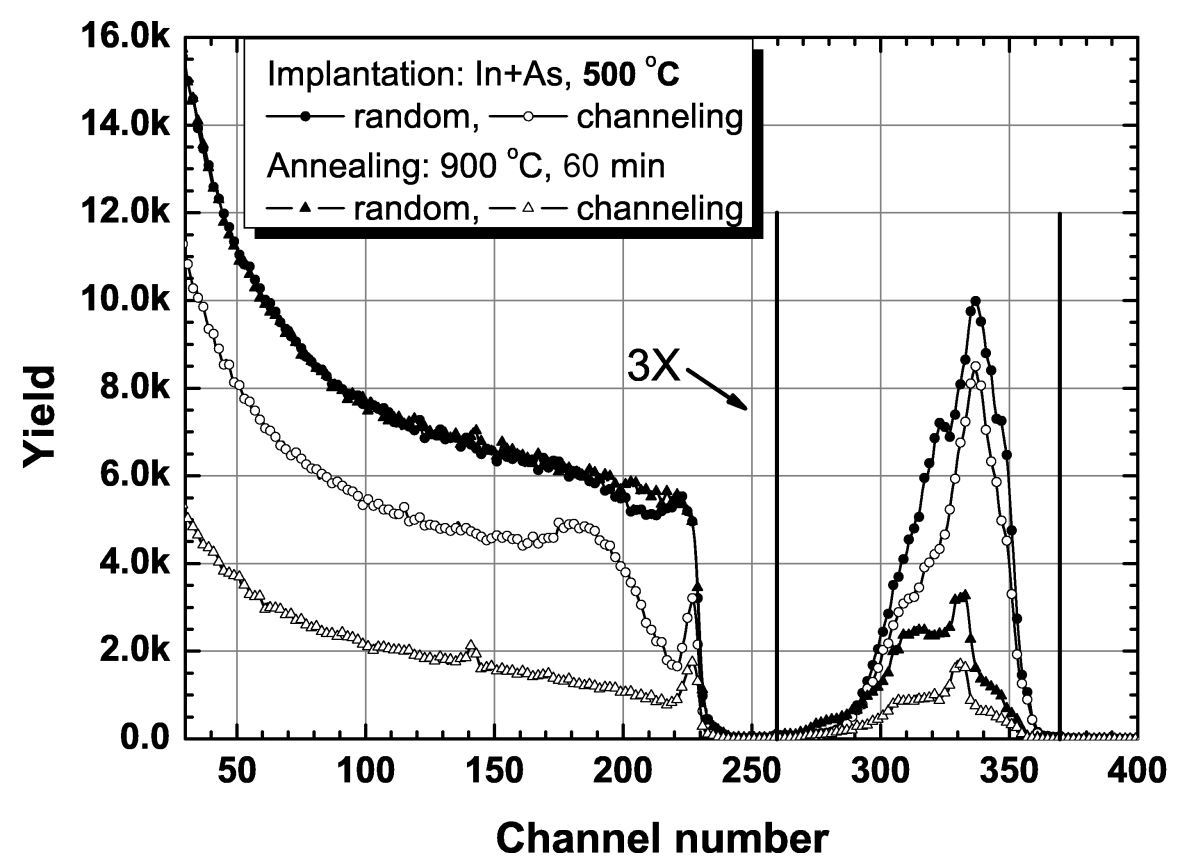

Fig. 2. RBS spectra of the Si sample implanted at $500^{\circ} \mathrm{C}$ with As $\left(245 \mathrm{keV}, 4.1 \cdot 10^{16} \mathrm{~cm}^{-2}\right)$ and In $\left(350 \mathrm{keV}, 3.7 \cdot 10^{16} \mathrm{~cm}^{-2}\right)$.

190 is related, in our opinion, to the existence of a defect zone located deeper than the impurity maximum. From the analysis of random and aligned spectra one can see the incorporation of impurity atoms into the regular lattice sites during the implantation. These peculiarities of "hot" implantation were observed in our previous experiments on InAs nanocrystals formation, too [4]. In the case of "hot" implantation the incorporation of more than a half of impurity atoms into the regular lattice sites is registered after the annealing. It should be noted that the aligned spectrum yield of backscattered $\mathrm{He}^{+}$ions of the implanted at $500{ }^{\circ} \mathrm{C}$ and annealed samples resembles the random spectrum yield more than that for the room temperature implanted and annealed samples. In other words, the crystal lattice recovery after the annealing of the room temperature implanted samples is more expressed than that for implanted at $500{ }^{\circ} \mathrm{C}$ samples.

The depth distributions of In and As in the implanted samples were evaluated using RBS / C. Strictly speaking, the analysis of As and In depth profiles was impracticable due to an overlapping of As and In peaks. In order to solve this problem, the RBS spectra of $1.4 \mathrm{MeV}$ $\mathrm{He}^{+}$ions were registered at two angles of ions' incidence: normally and at $50^{\circ}$ in respect of the surface. It allowed us to separate peaks from As and In and calculate the depth profiles for the both implanted species. In order to calculate these profiles, the RBS spectra were simulated until the whole coincidence with the experimental spectra registered for two angles of ion incidence.
Figure 3 represents the calculated (SRIM) and obtained from RBS spectra depth profiles of As and In atoms implanted in silicon at 25 and $500{ }^{\circ} \mathrm{C}$. It should be noted that at given ion energies the Gaussian distribution describes rather well both the experimental and the theoretical depth profiles. Thus, the noticeable diffusion redistribution of impurities embedded at room temperature is not revealed even under highfluence implantation conditions. One can see that "hot" implantation is accompanied by the significant diffusion redistribution of embedded atoms. The diffusion of both species towards the surface as the most effective sink for structure defects is predominant. The diffusion into the bulk of Si crystal is observed, too. The analysis of Fig. 3 reveals the loss of essential part of implanted atoms during "hot" implantation treatment. The calculated loss of As and In atoms amounts to 11.2 and $4.8 \%$, respectively. The calculations have not predicted any noticeable impurity redistribution due to equilibrium thermal diffusion at the implantation temperature of $500{ }^{\circ} \mathrm{C}$. The impurity redistribution under the influence of equilibrium thermal diffusion starts at $T_{\text {impl }}=900{ }^{\circ} \mathrm{C}$ only. The radiation-enhanced diffusivities of In and As atoms in $\mathrm{Si}$ at $500{ }^{\circ} \mathrm{C}$ were calculated using a numerical model described in Ref. [5]. The model takes into account the effects of ion-beam sputtering and radiation-enhanced diffusion. The radiationenhanced diffusivities were determined by means of fitting of depth concentration profiles to the experimental ones. In the case of implantation at $500^{\circ} \mathrm{C}$ we obtained diffusivity values of $D_{\mathrm{As}}^{*}=2.06 \cdot 10^{-17} \mathrm{~cm}^{2} / \mathrm{s}$ 


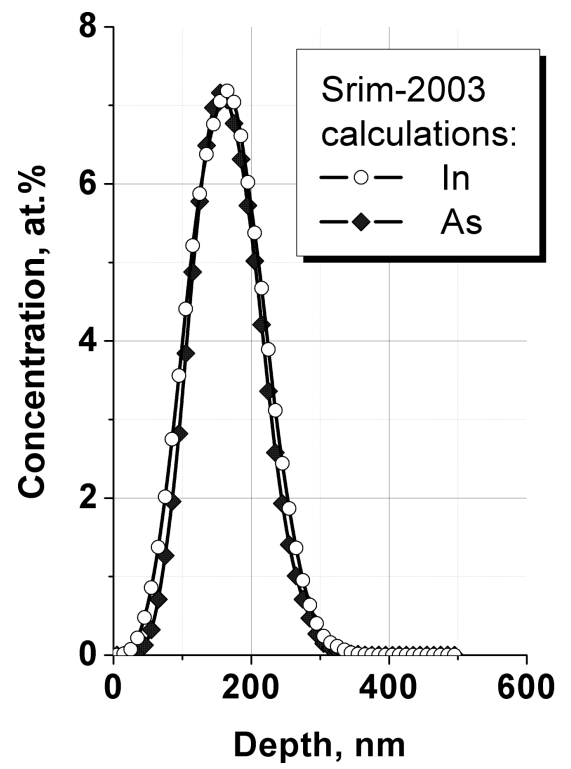

(a)

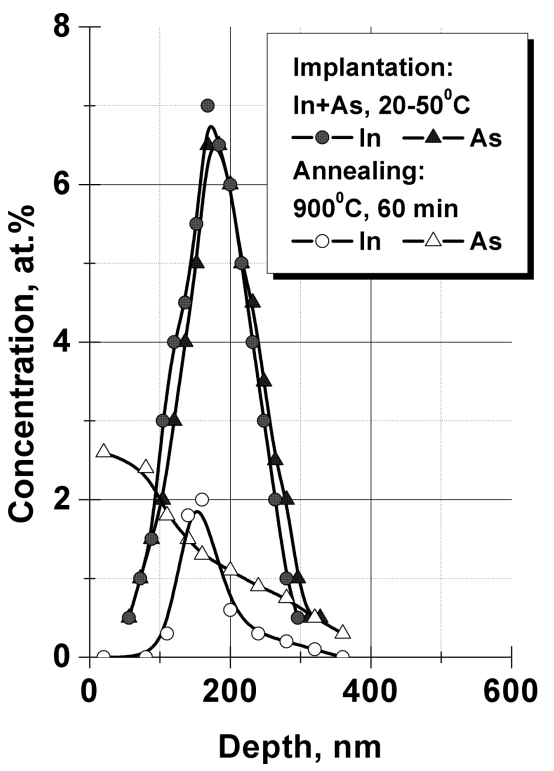

(b)

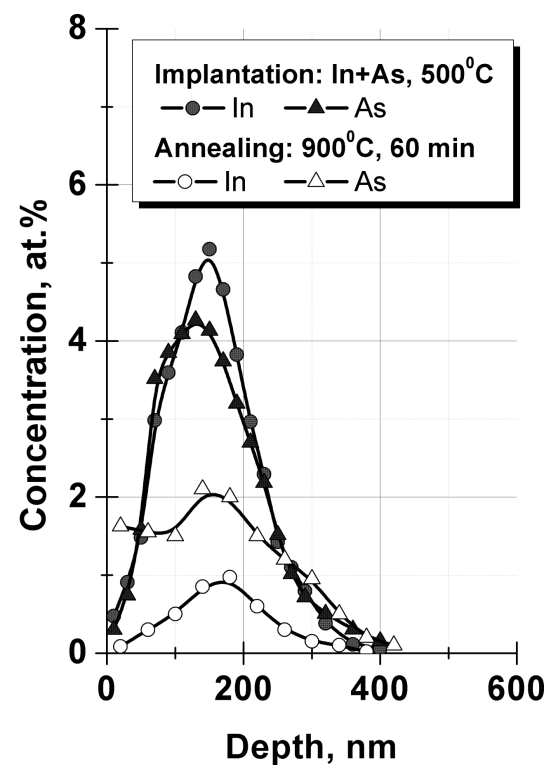

(c)

Fig. 3. (a) Calculated (SRIM 2003) and obtained from RBS spectra depth profiles of As and In atoms in silicon implanted (b) at the room temperature and (c) $500{ }^{\circ} \mathrm{C}$.

and $D_{\mathrm{In}}^{*}=6.94 \cdot 10^{-18} \mathrm{~cm}^{2} / \mathrm{s}$. These values are much larger than the calculated equilibrium thermal diffusivities of In and As atoms at $500^{\circ} \mathrm{C}$. Apparently, embedded species redistribution experimentally observed at $T_{\mathrm{impl}}=500^{\circ} \mathrm{C}$ is resulted from non-equilibrium radiation-enhanced diffusion caused by the migration of "impurity atom - radiation defect" complexes. Figure 4 shows the depth concentration profiles of As and In atoms implanted in silicon at 25 and $500^{\circ} \mathrm{C}$ and annealed at $900{ }^{\circ} \mathrm{C}$ samples. One can see from Fig. 3 that a rate of the implanted impurity loss increases significantly due to the annealing.

The high-fluence co-implantation of heavy ions such as In and As into silicon matrix leads to creation of system with high concentrations of implanted species as well as high densities of radiation defect complexes. Obviously, a decomposition of complex structure defects (microtwins and dislocation loops) takes place during the annealing. It is accompanied with the generation of great amount of point defects such as interstitial silicon atoms. It might stimulate the diffusional redistribution of implanted impurity by means of the diffusion of complexes "interstitial silicon atom-As" and "interstitial silicon atom-In" via interstitial mechanism.

\subsection{TEM data}

XTEM measurements show the formation of a heavily damaged crystalline layer with a thickness of about $300 \mathrm{~nm}$ after the (As+In) implantation (not shown). The disordered layer contains microtwins and precip- itates. The annealing results in a rearrangement of the defect structure of the damaged layer combined with a noticeable recovery of the crystalline structure.

Figure 4 represents bright-field XTEM images of the precipitates for the annealed samples. The TEM image of the sample implanted at $500{ }^{\circ} \mathrm{C}$ shows the presence of faceted nanocrystals with the sizes from 2 to $70 \mathrm{~nm}$. An interesting result has been obtained for the annealed sample implanted at the room temperature with As+In ions and afterwards additionally implanted with $\mathrm{H}_{2}^{+}$ions to create a getter layer (Fig. 4(a, c)). One can see the higher level of disorder in comparison with the sample implanted at $500^{\circ} \mathrm{C}$. Indeed, the subsurface damaged layer includes inclined dislocations and microcracks while the deep damaged layer at a depth of about $500 \mathrm{~nm}$ is characterized by a higher density of dislocation loops (see Fig. 4). At the same time the smallest clusters are registered in this sample. Their size ranges from 2 to $10 \mathrm{~nm}$. A detailed investigation reveals that these precipitates are identical ones with the smallest clusters observed in the sample implanted at $500^{\circ} \mathrm{C}$ (Fig. 4(d,e)). The crystalline nature of the precipitates is proved by the presence of moire contrast in the TEM images. We have analysed the distance between the moire bands using the procedure described in [4]. The experimental value of distance between the moiré bands is $1.8 \mathrm{~nm}$ (see insert in Fig. 4(c)). It is in a good agreement with the calculated one of $1.818 \mathrm{~nm}$ for the superposition of InAs and Si $\{220\}$ planes. Thus, a layer with InAs crystallites is formed in the annealed samples. In our previous paper the InAs nanocrystal formation in 

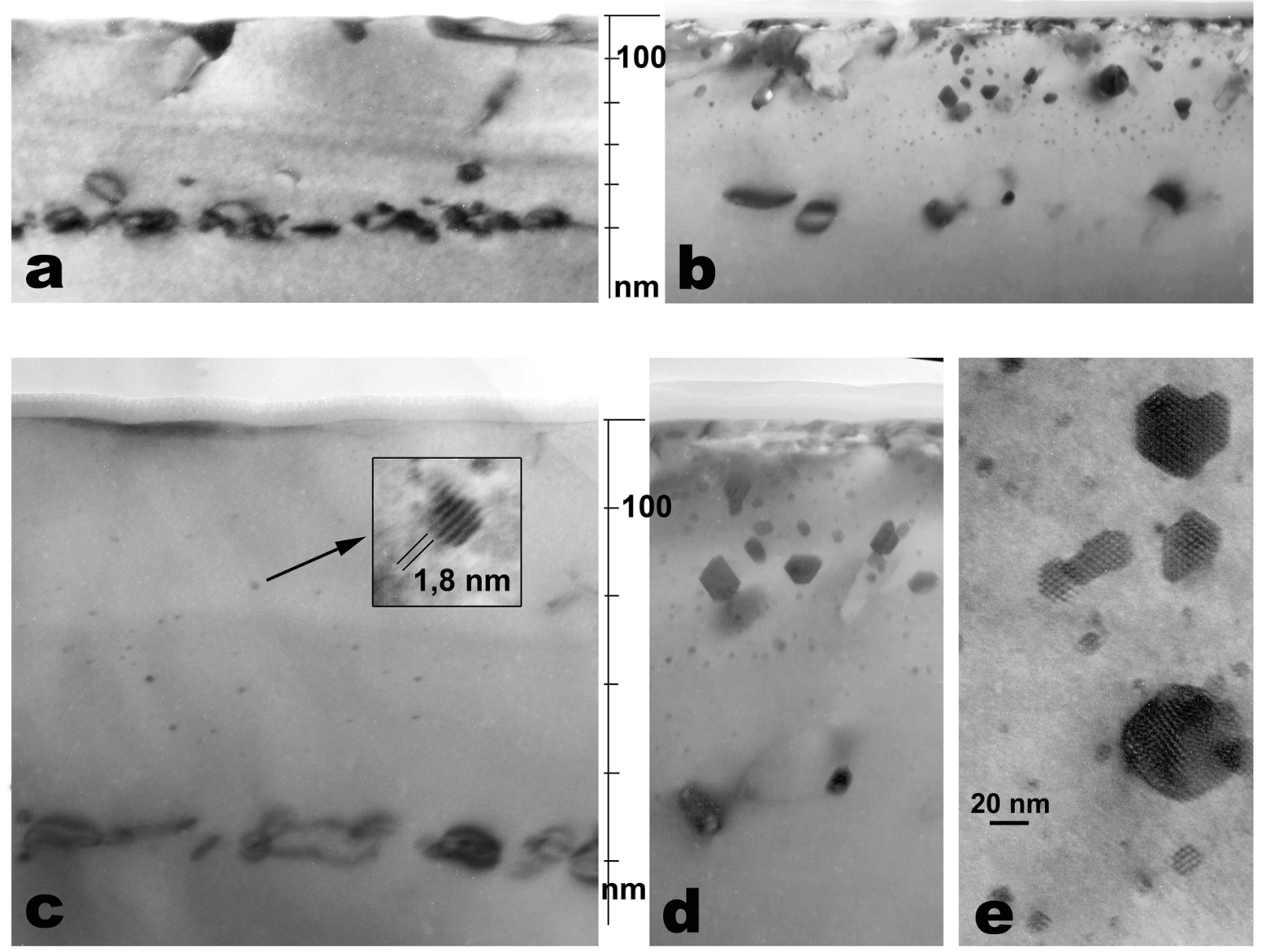

Fig. 4. Bright field cross-section images of the InAs precipitates in silicon matrix. Silicon has been implanted at (a,c) room temperature and (b, d) $500^{\circ} \mathrm{C}$ with As $\left(4.1 \cdot 10^{16} \mathrm{~cm}^{-2}\right)$ and $\mathrm{In}\left(3.7 \cdot 10^{16} \mathrm{~cm}^{-2}\right)$ and then annealed at $900^{\circ} \mathrm{C}$ for 60 min. (e) Image with higher magnification of the precipitates in the sample implanted at $500^{\circ} \mathrm{C}$. In order to verify the effect of getter on precipitates growth an additional procedure was carried out for the samples implanted with $\mathrm{As}$ and $\mathrm{In}$ species at the room temperature. This procedure included the implantation of $\mathrm{H}_{2}^{+}$ ions $\left(100 \mathrm{keV}, 1.2 \cdot 10^{16} \mathrm{~cm}^{-2}\right)$ before the high-temperature treatment.

Si matrix implanted at $500^{\circ} \mathrm{C}$ with $5 \cdot 10^{16} \mathrm{As}^{+} / \mathrm{cm}^{2}$ and $4.5 \cdot 10^{16} \mathrm{In}^{+} / \mathrm{cm}^{2}$ and annealed at $900{ }^{\circ} \mathrm{C}$ for 45 minutes have been studied [4]. Under the experimental conditions used in [4] the size of the precipitates ranges from 2 to $50 \mathrm{~nm}$. However, most of the clusters had dimensions between 3 and $6 \mathrm{~nm}$. Thus an increase of annealing duration results in a broader nanocrystal size distribution and larger average nanocrystal sizes. A possible reason for that could be the Ostwald ripening process in which larger clusters grow at the expense of smaller clusters. So the cluster size seems to be controllable in certain limits via the annealing time.

\section{Conclusion}

InAs nano-precipitates have been formed in crystalline silicon by high-fluence implantation at the room temperature and at $500{ }^{\circ} \mathrm{C}$ followed with the furnace annealing. In the case of the implantation at $500^{\circ} \mathrm{C}$ the cluster size ranges from about 2 up to $70 \mathrm{~nm}$. A comparison with the results of [4] has shown that the size of nanocrystals implanted at elevated temperature is influenced by the annealing time.

Interesting results have been obtained for the sample implanted at the room temperature with As+In ions and afterwards additionally implanted with $\mathrm{H}_{2}^{+}$ions. The higher level of disorder in comparison with the sample implanted at $500{ }^{\circ} \mathrm{C}$ has been found for this sample after the annealing. At the same time the smallest InAs clusters are registered in this sample. Their size ranges from 2 to $10 \mathrm{~nm}$. Thus, for samples implanted at the room temperature we have obtained the most narrow size distribution and the smaller average cluster size. The possible reason of these phenomena may be an effect of getter layer formed as a result of $\mathrm{H}_{2}^{+}$implantation. A detailed study of InAs precipitation in samples implanted at the room temperature is in progress.

RBS data analysis shows the better crystalline lattice 
recovery after the annealing for the room temperature implanted samples in comparison with the samples implanted at $500{ }^{\circ} \mathrm{C}$.

A significant loss of both implanted species has been revealed as a result of "hot" implantation conditions and post-implanted annealing. We have suggested that it is caused by non-equilibrium enhanced diffusion. The radiation-enhanced diffusivities have been determined for implantation at $500{ }^{\circ} \mathrm{C}$. The diffusivity values of $D_{\mathrm{As}}^{*}=2.06 \cdot 10^{-17} \mathrm{~cm}^{2} / \mathrm{s}$ and $D_{\mathrm{In}}^{*}=6.94 \cdot 10^{-18} \mathrm{~cm}^{2} / \mathrm{s}$ have been obtained using the model that takes into account the effects of ion-beam sputtering and radiationenhanced diffusion.

\section{Acknowledgement}

This work was supported by the Belarusian Republican Foundation for Fundamental Research (grants T08R-175 and F 08-150).

\section{References}

[1] R. Heitz, N.N. Ledentsov, D. Bimberg, A.Yu. Egorov, M.V. Maximov, V.M. Ustinov, A.E. Zhukov, Zh.I. Alferov, G.E. Cirlin, I.P. Soshnikov, N.D. Zakharov, P. Werner, and U. Gösele, Physica E 7, 317 (2000).

[2] A.L. Tchebotareva, J.L. Brebner, S. Roorda, and C.W. White, Nucl. Instrum. Methods B 175-177, 187 (2001).

[3] F.F. Komarov, L.A. Vlasukova, O.M. Milchanin, P.I. Gaiduk, V.N. Yuvchenko, and S.S. Grechnyi, Vacuum 78, 361 (2005).

[4] F. Komarov, L. Vlasukova, W. Wesch, A. Kamarou, O. Milchanin, O. Grechnyi, A. Mudryi, and A. Ivaniukovich, Nucl. Instrum. Methods B 266, 3557 (2008).

[5] P. Zukowski, C. Karwat, F.F. Komarov, A.F. Komarov, and A. Latuszyński, Phys. Status Solidi A 157, 373 (1996).

\title{
IMPLANTACIJOS IR ATKAITINIMO REŽIMŲ ITAKA JONŲ PLUOŠTELIU SINTETINANT InAs NANOKRISTALUS
}

\author{
F. Komarov ${ }^{\text {a }}$, L. Vlasukova ${ }^{\text {a }}$, O. Milchanin ${ }^{\text {a }}$, A. Komarov ${ }^{\text {a }}$, W. Wesch ${ }^{\text {b }}$, A.K. Togambayeva ${ }^{c}$ \\ ${ }^{a}$ Baltarusijos valstybinis universitetas, Minskas, Baltarusija \\ ${ }^{\mathrm{b}}$ Frydricho Šilerio universiteto Jenoje Kietojo kūno fizikos institutas, Jena, Vokietija \\ ${ }^{\mathrm{c}}$ Al-Farabi Kazachijos nacionalinis universitetas, Almaty, Kazachija
}

\begin{abstract}
Santrauka
Aprašytas nanomatmenų InAs kristalitų silicio matricoje susidarymas implantuojant As $\left(245 \mathrm{keV}, 4,1 \cdot 10^{16} \mathrm{~cm}^{-2}\right)$ ir In $(350 \mathrm{keV}$, $3,7 \cdot 10^{16} \mathrm{~cm}^{-2}$ ) atomus. Implanatuota esant 25 ir $500^{\circ} \mathrm{C}$ temperatūrai. Norint patvirtinti geterio (sutraukimo) reiškini nuosèdoms augant, As ir In implantuoti pavyzdèliai papildomai apdoroti kambario temperatūroje: jie apšvitinti $100 \mathrm{keV}$ energijos $1.2 \cdot 10^{16} \mathrm{~cm}^{-2}$ $\mathrm{H}_{2}^{+}$jonu srautu. Po to pavyzdèliai buvo $60 \mathrm{~min}$ atkaitinami inertinèje aplinkoje $900^{\circ} \mathrm{C}$ temperatūroje. Implantuotiems sluoksniams apibūdinti naudoti Rezerfordo atgalinès sklaidos spektrometrijos su
\end{abstract}

kanaliniu nukreipimu (RAS / K) bei peršvietimo elektroninès mikroskopijos (PEM) metodai. Implantuotuose pavyzdèliuose po atkaitinimo PEM rodo esant nanomatmenų InAs kristalus. Išsiaiškinta, kad vidutinis InAs klasterių dydis ir dydžiu pasiskirstymas priklauso nuo implantavimo temperatūros ir atkaitinimo trukmès. Rasta, kad po „karšto“ implantavimo ir poimplantacinio atkaitinimo i̊vyksta žymus implantuotų medžiagų difuzinis persiskirstymas. Kai esant aukščiau minètoms eksperimento sąlygoms implantavimas yra „karštas“, dèl apšvitos išsklidimas padidejja. 